\title{
Komunitas Lima Gunung: Concept of Art Communitas on Five Slopes of Central Java, Indonesia
}

\author{
Brian Trinanda Kusuma Adia,1,*, Samsul Ma'arif b,2 \\ ${ }^{a}$ Universitas Gadjah Mada, Jl. Teknika Utara, Yogyakarta, 55281, Indonesia \\ ${ }^{\text {b }}$ Universitas Gadjah Mada, Jl. Teknika Utara, Yogyakarta, 55281, Indonesia \\ ${ }^{1}$ brian.disini@gmail.com*; ${ }^{2}$ samsul.maarif@ugm.ac.id \\ * corresponding author
}

\section{ARTICLE INFO}

\section{Article history}

Received 2020-08-19

Revised 2020-08-28

Accepted 2020-09-03

Keywords

Komunitas Lima Gunung

Communitas

Performing arts community

Folk Art

Festival Lima Gunung

\begin{abstract}
Komunitas Lima Gunung (KLG, the five-mountain community) was founded in 2002 by Sutanto Mendut - a well-known budayawan (cultural practitioner). KLG refers to communities living in areas of the five mountains of Magelang, Central Java that together join into one single community, the KLG. Those mountains are the Mount Sumbing, Merbabu, Andong, Merapi, and Menoreh. Sutanto Mendut, the president of KLG, builds the community with the characteristics of what Victor Turner may call communitas, which is traditionally inherited in the calendrical ritual performances of KLG in which those groups of people continually re-articulate and re-contextualize their worldviews and social norms and orders. This research examines those ideas of communitas as forged in the KLG. This research was conducted through fieldwork: participant observation and unstructured interviews. Data were collected by participating in and documenting several activities (performances). "Meanings" of those performances were gathered through a series of unstructured interviews with practitioners that included Sutanto Mendut himself, leaders of the communities, and many members of the KLG. This research is indebted to theories of performance studies to analyze those collected data. The results of this study indicate that first, society emerges through ritual performances that create moments of liminality. This moment is the result of the re-articulation of the anti-norms/social order structure/structure. Second, Sutanto Mendut, through the Land Oath (Sumpah Tanah), re-articulated the sense of togetherness of KLG to become the Five Mountains Festival (FLG). Third, KLG is the strength of the community; members learn about freedom and are not dependent on established social structures. They are free to feel the moment of togetherness.
\end{abstract}

\section{Introduction}

In Central Java, several communities live on the slopes of the mountains, and they use "art" as a vital force in their lives. That is, however, not because the members of the communities spend their whole life as an artist; art is not what they do for a living; most of them are practically a farmer, instead. Nevertheless, in many cases, those farmers are always ready to spend a considerable part of their income on art. As well as ritual performances, art performances are funded from the sum of money they collect from their hard work, from sowing and harvesting their corn, chili, cabbage, and bean. In some ways, a consistency to do this kind of way of life also grows up because they are supporting each other as they build a relationship as the big family of Komunitas Lima Gunung (KLG/the Five-Mountain Community). KLG was founded in 2002, initiated by Sutanto Mendut. The members of this community come from the slopes of five mountains and foothills in Magelang 
regency of Central Java: Mount Merapi, Merbabu, Sumbing, Andong, and Menoreh foothill. In the same year, that community held the first Festival Lima Gunung - FLG (Five Mountains Festival) I. To do that, Sutanto had to visit the country-sides and invite many communities from the five mountains to join art performances in the festival, altogether [1]. Uniquely, somewhat different from other internationally recognized Festivals, KLG is performed independently without any sponsorship. In holding their annual festival-Festival Lima Gunung, they are not bothered by looking for a donation, or "getting entrapped" in counting out the donation/sponsor funding to get back their expenses or any money they have spent.

The Festival, which is performed independently, is one among many examples indicating a "particular principle" forged by KLG as more than just an art-based community. Since its establishment in 2002, as the firs FLG was held, there were uncountable individuals and communities involved temporarily or permanently (become the members of the community). This community does not only belong to groups of (farmer-artist). However, it consists of many individuals and communities from many different social status and background, such as politicians, entrepreneurs, religious authorities, academicians, and many other kinds of (or groups of) persons. Even though most of them, indeed, gather in KLG through artistic processes, it would be too simplistic to call them merely as an art-based community. Also, even though most of the KLG members are "farmer-artists" who come from five different mountainous areas of Magelang regency, it seems pretty clear that it is practically a borderless community. Therefore, due to its complexity, KLG is not easy to define as one single unit of the community. However, one sure thing is that KLG is a space of gathering, the meeting point that opens to many kinds of a possible relationship.

The five-mountain community (KLG) has undeniable complexity because, in it, a dialectical process occurs continuously. According to Turner, communitas is much different from the structure. Turner argues, communitas is in the present, whereas the structure originates from the past and moves into the future, whereas the movement occurs through language, law, and habit. It occurs through language, law, and customs [2]. The understanding of "The now" from the community shows its antistructured character and represents "quick." According to Turner, this idea becomes an existential quality of the communitas. This is due to the complete human involvement with other humans [3].

This concept of communitas helps to understand the social life of KLG, both as (a single) community and (a collection of) communities. As a single unit of the community, KLG provides a vast space in which people are no longer side by side yet becoming "one" with another multiple people-I-Thou relationship - as opposed to "structure" or "community," which is hierarchically structured and institutionalized. In this scheme of writing, researchers use both terms alternately in which researchers were dealing with communitas as a concept [3]. At the same time, community means as a group of people - not as a term opposed to communitas. Turner defines communitas in accordance to the I-Thou relationship concept of Buber [4]. When Buber uses the term communitas, he is not, in the first place, talking about persisting social groups with institutionalized structures. However, for Buber, the community is quintessentially a mode of relationship between total and concrete persons, between I and Thou [5].

Buber's definition of a community is not a "structured" community but a community with a sense of communitas. The sense of communitas in KLG is a re-articulation of the community spirit that is rooted in community life in the five mountains. This sense of communitas is vital since it is only through this sense [6], many communities living in the five mountains which have specific territorial locus and limited can be gathered into one single community known as KLG. The emergence of communities on the slopes of five mountains is thought to have an anti-structure nature. The relationship between people characterizes the quality of the existence of KLG - community members are interdependent with other members. They build a complete connection with other members ( $I$ Thou). Another consequence of the anti-structural nature of the community is its potential aspect. Anti-structure is a subjective atmosphere, in which the relationship between humans is generative of symbols, metaphors, and comparisons between art and religion, legal and political structures [7]. Hence, by placing art and religion as a product rather than as a legal structure, people in (or who is experiencing) communitas have more flexibility in showing their artistic and religious expressions. In communitas, creativity, then, does not only belong to the artist but also the religious sphere. It is almost everywhere held to be sacred or 'holy,' possibly because it transgresses or dissolves the norms that govern structured and institutionalized relationships and is accompanied by experiences of unprecedented potency [8]. 
In this sense, rather than diminishing it, creativity has become the very soul of religion for the people living in communitas [9]. The idea of creativity is at the soul of KLG, and this signifies a "performative turn" in this study. The performative turn asks us to jump from a matter of "archive" study to "survive" the moments of its doing. Davis considers this change to be a performance problem because the process of seeing, feeling, and knowing has an impact on the outcome of the description and the attitude of documenting it [10]. Studying KLG in the sense of revealing the definition of community in the life of a mountain slope community means uncovering social problems. An interesting finding is that individual behavior is the result of collective influence. Why? Because individual actions are carried out consciously, and all behavior that is done intentionally can be understood openly by anyone.

\section{Method}

Research data collection strategy through fieldwork from 2019 to February 2020. The fieldwork included participant observation and (unstructured) interviews. So far, researchers often visit and participate in KLG activities. The researcher stayed for several days at the Mendut Studio; the studio is Sutanto Mendut's house, which is located in the Menoreh mountain area. This place has been the KLG "headquarters" for years. In the studio, all members of the KLG, such as Padepokan Wargo Budoyo Gunung Merbabu, Gunung Sumbing Cahyo Budoyo Studio, Andong Jinawi Studio Gunung Andong, Padepokan Tjipta Boedaja Mount Merapi, held fine arts and performing arts activities. Researchers also make some documentation (photos and videos or short films).

The analysis is done through data triangulation of observation, interviews, and other secondary sources [11]. Any other types of literature such as books, newspapers, and other sources had also become necessary sources, especially by considering that many of KLG and Sutanto Mendut's programs, such as Festival Lima Gunung, have been well documented by many newspapers. The data analysis process was carried out by paying attention to the KLG performance mode. The triangulation stage is codifying the entire performativity process; in the next step, perform an analysis of the existential interlocking function. At the same time, the data of the category of actions and daily performances are assessed mostly through interviews and direct observation [12]. The definition of communitas was understood from the start when analyzing the "culture" of KLG. Performance theory is used to see this definition. This process is carried out by paying attention to the cultural fabric that exists in society. At this stage, unstructured sequences or systems of dynamically expressed sequences of actions receive serious attention [13].

In performance studies, every human action which is framed, presented, highlighted, or displayed is considered as a performance [14][15]. In this sense, the whole span of human development, including social action, as a large-scale collective effort, can be studied as performance. This study emphasizes the understanding of the uniqueness of an event based on its interactivity and not materiality. Therefore, in this perspective, every social action is not framed as a representation of a given meaning structure, but as an expressive, communicative, and agonal movement that forms meaning [16]. Those actions that are analyzed range from the local performances of ritual, which are considered as very significant in the lives of communities living in those five-mountains to the more significant scope of performance such as FLG developed from those local performances.

\section{Results and Discussion}

\subsection{The Functions of Ritual Performances for Communitas}

There are many moments inside the ritual performances held by the KLG in which their "social orders" are simultaneously re-produced through the process of liminality (in the intersection between structure and anti-structure). This process of liminality is a margin, one among three phases of transition (segregation, liminal period, and reaggregation), which is shown in all rites of passage [17]. "Segregation" is the anti-structure, signified by the detachment of people or a group of people their earlier fixed point of social structure; "reaggregation" is a consummation of certain customary norms and ethical standards; while "liminal period" is the margin of both processes, the ambiguous. According to Turner, the liminal entity is neither here nor there; but liminal is in an intermediate position which has been determined and regulated by norms, laws, customs, and conventions [18]. However, Turner added, we cannot deny the fact that only within this ambiguity, a wide variety of 
symbols in the many societies that ritualize social and cultural transitions is expressed. The emergence of communitas or communitas spirit is in the liminal period or is called the process of liminality. According to Turner, liminal is a combination of humility and innocence, homogeneity, and brotherhood. Turner also argues that what emerges clearly in the liminal period is society as unstructured and relatively indistinguishable communitas or even association of equal individuals who submit to the general authority of the ritual elders [2].

Those liminal periods, again, as Gennep [19] and Turner [2] argue, are a crucial transitional part within any ritual performances, which builds the sense of communitas as the fundamental element for any community lives. Those liminal periods appear in all calendrical rituals such as all Merti Dusun: Saparan and Rejeban in Mantran Wetan (the mount of Andong), Krandegan (the mount of Sumbing), Tutup Ngisor (the mount of Merapi), and Gejayan (the mount of Merbabu). The liminality of Merti $\operatorname{Dusun}(\mathrm{s})$ allows them to play the primary functions of ritual, which is to foster community by maintaining their communal solidarity. It proves by the fact that, though having particular official religion as their identity (such as Muslim or Christian followers) or having a particularly special status in their office, nobody living in each community who dare not to get involved or to take his part in preparing these annual events. Each person's contribution, though it may be varied depending on each capability. In the Rejeban ritual in Gejayan, for example, several family members are responsible for preparing Tumpeng, and this is passed down from generation to generation; some other families are accountable for preparing Sesajen (offerings), and many others are responsible for others. In Figure 1 are the Sesajen brought for the Rejeban ceremony at Telompak.

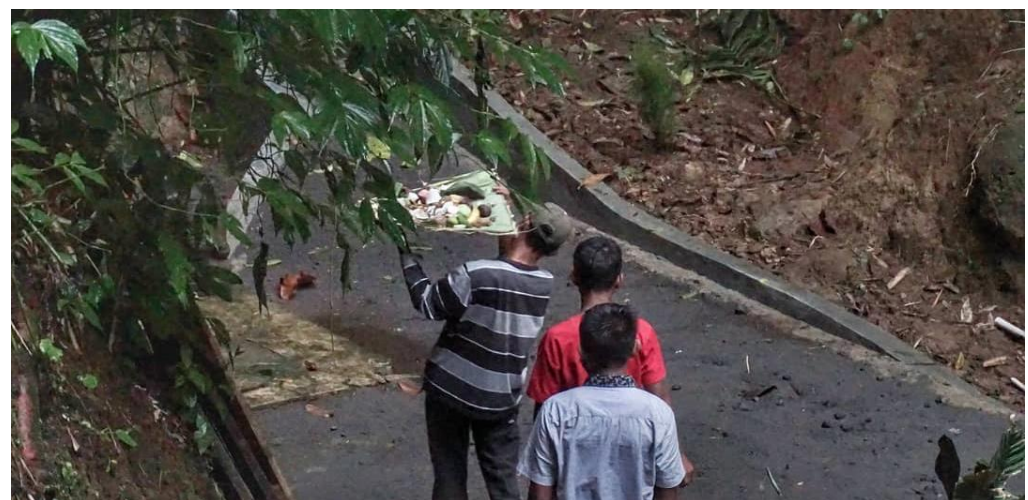

Fig. 1. Placing Sesajen (an offering) at Telompak in the ritual of Rejeban

Nobody in the community asks them to do so; however, since it has been done inter-generationally, those individuals (who are responsible) thought that the ritual must be incomplete without their contribution. Any compulsory contribution, such as funding that is collected from each family, is decided in a community meeting considering the average financial condition in the community. Other contributions such as preparing the stage for the ritual is organized, yet it is executed voluntarily. Once in the afternoon, a moment I visit Telompak, a sacred site in Gejayan sub-village-some weeks before Rejeban is held-I saw a man cleaning the site all by himself. When I asked him about the reason why he was doing it all by himself, he told me that his group who is responsible for cleaning the site on that day had been coming and finished their job earlier in the morning (as scheduled). Considered this cleaning schedule as a fundamental responsibility, he was committed that he also should take his part like every other guy in his group had done. However, he was late, did it by himself, and though nobody asked him to do so. As for the people living in Mantran Wetan, nobody in this village who is not preparing at least an Ingkung (a full shape of chicken) Ingkung can be seen in Figure 2, Sesajen (offering), Tumpeng Sewu, and meal for visitors who may visit their house. Everyone has the same kind of contribution, though it may be different in numbers. These kinds of equal and co-working spaces significantly characterize the celebration of Merti Dusun. Maintaining these events collectively is a must, as I found in all interviews with some citizens; all of them strictly state that nobody in their community would dare enough not to do so. Though most of the informant admitting to being Muslim followers, not much of them are routinely do five-time prayer, not much of them who are routinely do Friday prayer, but none of them who dare to absent in doing this annual event of their community, known as Merti Dusun. 


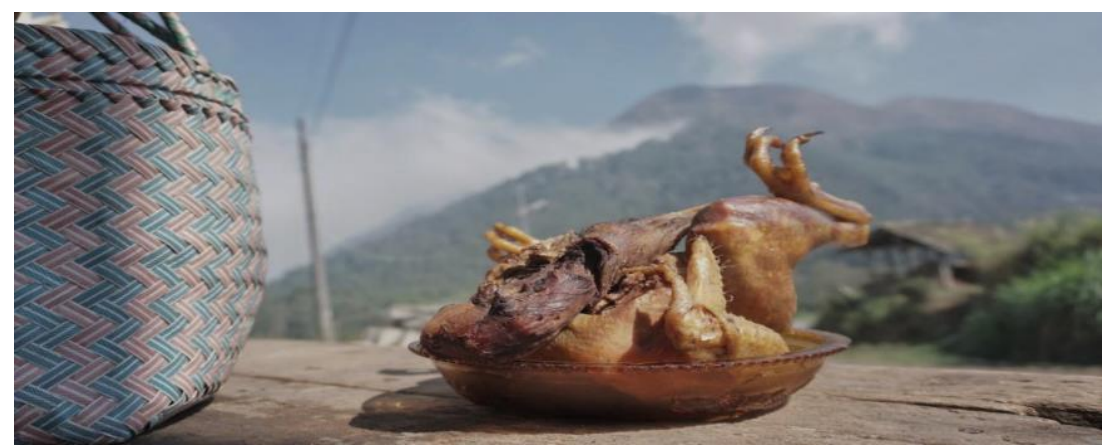

Fig. 2. An Ingkung in the rite of Ingkung Sewu

The liminality of Jaran Papat performance in Mantran Wetan and Sungkem Telompak performance in Gejayan also transforms the art performance (the dance of Jaranan in Jaran Papat) and a stage of the performance (Telompak fountain) to function as a performance to heal. As shown in Figure 3, the climax of Jaran Papat-which is the liminal period of the performance, whenever the performers are in a trance, many people come to speak to them in order to ask for the solution to the problems they have in their daily lives. Most, if not all, a group of people who come from Keditan to Gejayan sub-village in the moment of Sungkem Telompak also drink or bring back home the water from the sacred fountain that is believed to be able to heal many kinds of sickness. Because of the "magic" (liminality) of Sungkem Telompak performance, people from Keditan and people living in the Gejayan sub-village never use the water from this fountain as for domestic need, except for bersuci (cleaning their body in a spiritual sense) and for medical need.

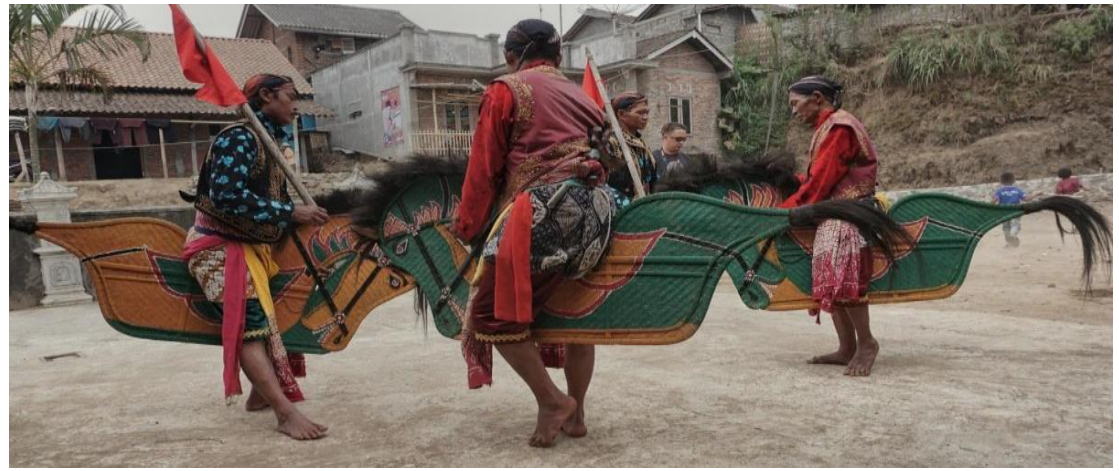

Fig. 3. Jaran Papat Performance

Although it is not entirely different from Merti Dusun in the other three sub-villages, which must be done communally by the whole community and to foster community, suran in Tutup Ngisor highlights another significant liminal function in its relation to its community. The function of this event dealing with sacred and demonic is more emphasized than any other function. The month of Sura is considered sacred for Javanese. This month is believed to have a spiritual and mystical danger. Wayang Wong Sakral (Sacred Wayang Wong) performed in this month is the way for Tutup Ngisor citizen to negotiate with this spiritual danger through liminality. Despite performing a particular story, there are many kinds of mantra recited by the performers throughout this a whole night performance. All mantra, to put them merely, are about asking for the gods - according to Javanese Puppet biblesto place their grace in this place. In the performance, those gods' grace and permission signify liminal periods, which are symbolized by some keris (traditional Javanese knife) that are given by the gods to punakawan (a figure in Javanese puppet show) that represent Tutup Ngisor citizen. This performance is also repeating what has been done by Romo Yoso (Tutup Ngisor's mystical figure) in the first establishment of this sub-village. It was told that Romo Yoso's family is one of the first citizens of Tutup Ngisor. Long ago, there was no Tutup Ngisor, but Tutup, a sub-village placed some kilometers above-around 500 masl or more-Tutup Ngisor, which is located in around 400 masl. Tutup Ngisor is the expansion of the Tutup sub-village - that, now, is known as the Tutup Nduwur sub-village (Nduwur is the Javanese language means above, while Ngisor means below). Before the coming of the Romo Yoso family, Tutup Ngisor is a forest area. As commonly known by Javanese, a forest where no human inhabitants are the residence of the devil, either known as Jinn or Danyang. A special rite is required to negotiate with those other beings, significantly whenever the human inhabitants 
have been increasing into a significant number. The increasing human inhabitants in Tutup Ngisor were followed by famine and the risk of haunting death ones who dared to build a new house. In his prayer, Romo Yoso heard a piece of advice to perform a Merti Dusun as a way to "clean up" the village from danger as well as to negotiate with "other beings." Romo Yoso performed the first Sacred Wayang Wong as the main event of that Merti Dusun. It is believed that Sacred Wayang Wong that is performed is not much different from what was performed by Romo Yoso, and the sacred Wayang Wong performance can be seen in Figure 4.

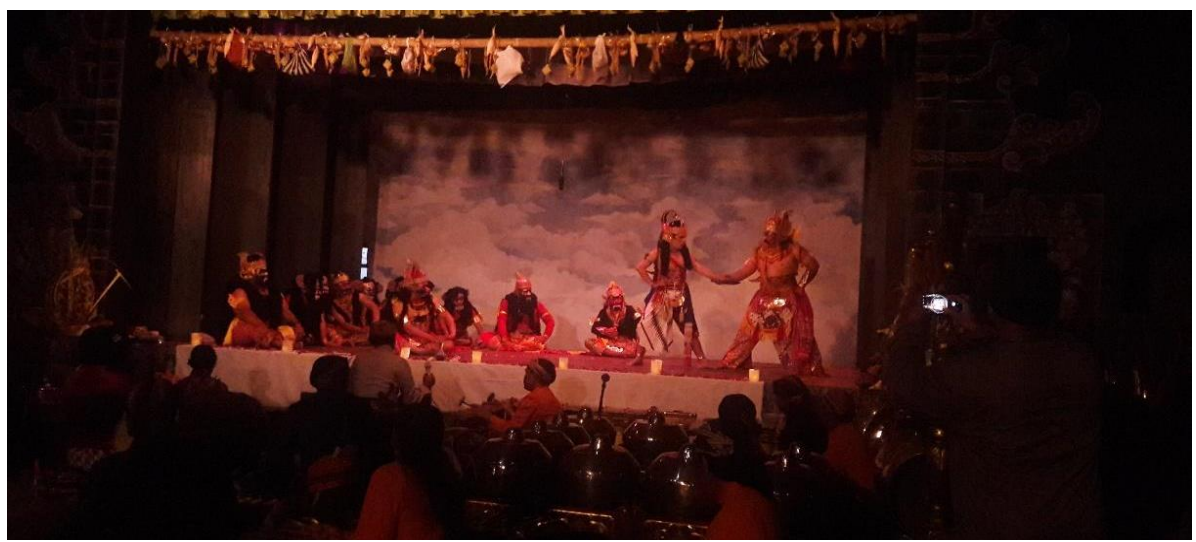

Fig. 4. Wayang Wong Sakral Performance

The function of the performance of Wayang Wong Sakral in Tutup Ngisor sub-village resembles Sungkem Telompak in Gejayan sub-village, which is performed to commemorate the connection between the people living in the Keditan sub-village and the Danyang living in Telompak sacred fountain known as Prabu Singa Barong, which is believed to have saved those people in the time of famine happened a long time ago in the history. Sungkem Telompak rite begun as a performance dealing with the sacred and the demonic, which gradually regains new function not only to entertain but also to make or foster two communities that are living side by side in harmony (Gejayan and Keditan sub-villages). In its development, Sungkem Telompak that was previously performed only by the Keditan sub-village, becomes the communal event of two sub-villages in which the Gejayan subvillage not only welcoming the community of the Keditan sub-village that routinely once in a year performs Cucuk Bawur performance in the area of Telompak but also helping them by renovating the sacred site, preparing a beautiful stage, and inviting many other groups of art to show many art performances. There was a liminal period, a moment of metaphysical communication-I recorded from my interview with Riyadi, the leader of Sanggar Wargo Budoyo, Gejayan, who instigates the development of Sungkem Telompak - in the celebration of recent Sungkem Telompak when one of the performers from Keditan sub-village who were in a trance, possessed by Prabu Singo Barong, expressed his happiness for this such development.

However, no one also denies the functions of those whole communal events in each community as entertainment that successfully please a public who come to enjoy the event. The main events such as Jaran Papat, 24 hours of Tayub dance, Wayangan (shadow puppet performance), Sacred Wayang Wong performance, and many other performances arranged in the three-to-five day events of Merti Dusun, Suran, and Sungkem Telompak are, to some degree entertain public who come to the performances. Those functions of ritual performances indicate the liminal phenomena/period in which lowliness and sacredness, of homogeneity and comradeship, are blended simultaneously. These also indicate the communion of equal individuals who submit together to the general authority of the ritual elders as one of the characteristics of communitas within community practices [2].

\subsection{The Other Elements of Communitas in the Ritual Performance}

Merti Dusun, whenever they might be held and whatever they might be named, whether they are Saparan, Rejeban, Suran, Ingkung Sewu, or Tumpeng Jangka and other calendrical resembles it such as Nyadran and Sungkem Telompak, are acts of communitas. Whenever they do so, they are making contact with "the power," whatever the power might be imagined, to renew their relationship with it. It is, thus, their fellowship with those kinds of "power" that made any environment possible. It is the sense of spirituality when communitas is arising, a moment when the village holding the event is situated on "a liminal place," betwixt and between their relationship toward their surroundings. The 
delightful sense of communitas, though, it may last only in a half-hour, two hours, or in a full day and night, is a transmutation of communitas into a sense of siblinghood that can be felt not only by those all villagers but also by anyone engaged in any of those kinds of ceremonies. I have experienced those all communitas elements during my fieldwork. Suran in Tutup Ngisor sub-village, mount Merapi is the first Merti Dusun in KLG that I visit during my fieldwork. To the people of Tutup Ngisor, I am a stranger, no one living in this village I had ever met, except only a note consisting of some recommended names of persons I have to meet as my essential informants. One of them, as I considered as the most important key person to look for, is Sitras Anjilin, the leader of Padepokan Tjipto Boedaja.

Though I felt awkward to visit a place I never knew and the house of a person - whose I have never seen face to face before, I must be lucky due to a moment I came when the sense of communitas, a less structured situation, i.e., Merti Dusun, when everyone - included a stranger - is treated equally with honor, did arise in the environment. This honor appeared in a respectful welcome, a humorous conversation, and a dinner table full of prepared food - in which anyone who visited might be offered to eat even more than five times in a day. I went back and forth from Sitras's living room to the stage performance located just in front of his house, where the most sacred performance of this ceremony, Wayang Wong Sakral, was performed. Just within some hours of visit spent mostly by talking, eating, and observing the performances, the feeling of awkwardness and strangeness seems to have quickly disappeared. The villagers even offered me - and many other guests coming that evening - to spend the night in their houses, so I can take some rest and have a chance to watch other performances held in the early morning, kirab jathilan, and other sequences of the ceremony of Suran that would be performed next day. This whole treatment is a sense of communitas, accomplishing even the words cannot, to tell everyone "we are friends," though, without saying anything. The Wayang Wong Sakral performance and many other sequences of this ceremony are inherently communitas purposing to maintain a relationship with "other beings" believed to exist in their surroundings. Those other beings vary, ranging from dhanyang (powerful spiritual beings), cikal bakal (their ancestors), dhemit (demonic beings), pepundhen (sacred sites), and many other else.

In a full day observing Merti Dusun or Saparan in Mantran Wetan sub-village, mount Andong, I find the same sense of communitas I felt during my fieldwork in the Tutup Ngisor sub-village. The whole sequences of the rite of Tumpeng Jangka and Ingkung Sewu ranging from the parade, incense burning, praying, and are communitas. When the shalawat is chanted altogether during the parade, there is a clear sense of communitas element seen on the chant that entwines those people together into a single unit. The same atmosphere can be felt whenever there is a Muslim die in Java. In most cases, this Muslim's dead body would be carried to the graveyard by a group of people followed by other groups of people, whether they are dead's family, friends, or neighbors - whether they are Muslim or not - who walk behind the people who carry and all together chant shalawat to express their grievance and prayer for the dead. It might be said that the chant of shalawat has provided a space of communal connectedness through mystical participation. Mantran Wetan community or people who escort the dead to his/her grave do not form this mystical participation, and it has been there all the time, everywhere, the chant of shalawat is only a way among other else. In such a moment, anyone is allowed to follow or join this chant because this kind of mystical participation must be greeted either with joy (for the Ingkung Sewu parade) or grief (for escorting the dead). It is the element of communitas of this mystical participation, in which, though Islamic in appearance, it does not have the flavor of any institutional religion, i.e., Islam, so that anyone, despite their religion, can join in to express their feeling. At the end of this parade, a person who is considered as the village religious leader leads the prayer while burning kemenyan (incense extracted from menyan tree's resin). If it were "institutionalized Islam," instead of this communitas element taking place on this chanting and the whole sequences of this rite, they would be no kemenyan (incent) that was burnt in the last sequence of this parade, as they would even no parade at all. Ingkung, tumpeng, sesajen (offerings), this incense is considered un-Islamic by the most dominant institutionalized religion in Indonesia.

Though the parade of Ingkung Sewu (and Tumpeng Jangka) performed in the morning and later followed by Jaran Papat performed in the noon (in the day of the ceremony) are iconic characters for the community of Mantran Wetan, no explanation I can trace about when and how Ingkung Sewu and Jaran Papat were begun in history, what I know is that it is compulsory for each family living in the community of Mantran Wetan to prepare at least a full-shaped of Ayam Kampung (locally farmed chicken) to be paraded in the day of Merti Dusun which dated in a particular day in the month of 
Sapar (according to Javanese Calendar). Despite the parade of Ayam Kampung held in the morning and the performance of Jaran Papat started in the noon that is considered as the very sources of the tradition, the rest of the event are improvisations. Even the name of Ingkung Sewu and Tumpeng Sewu, for instance, is relatively new (kind of improvisation). Although it has become a tradition to prepare those all Ayam Kampung, none of their ancestors naming this tradition as Ingkung Sewu. This name was arranged by Supadi Haryanto himself, one among many honorable elders in this community that is coincidentally also a leader of KLG. Tumpeng Sewu was another of Supadi's improvisation to enliven this event. Tumpeng Sewu consists of necessary elements of offerings for the ritual of Ingkung Sewu that was previously kept inside every house. It was Supadi's idea to ask each family of Mantran Wetan whose houses are passed by in the parade of Ingkung Sewu to put this offering in front of their house as decoration. Besides the parade of Ayam Kampung or Ingkung Sewu and the performance of Jaran Papat, everything else exists in this ritual are "an open space" for everyone to express their idea. In the middle of the ritual, as an example, Sutanto Mendut gave a speech containing a suggestion to encourage women of this community to join in the parade in which, for him, seemed to be too mancenter. Everyone listened and seemed to agree with this suggestion. Even a journalist who interviewed Supadi suggested some criteria of costumes Mantran Wetan community might wear for the parade so they might have a better photograph; Supadi agreed on it. This kind of creativity: to name things and to arrange new things into a tradition and as the sense of an "open space" in which many people, though apparently "outsiders" seen from a local perspective, can interact and engage with inherently shows the element of communitas.

Twenty-four hours tayub dance performance that is considered as the iconic character of Merti Dusun or Saparan in Krandegan sub-village, mount Sumbing is the element of communitas that shows the moment when the people of Krandegan is re-connected to their cikal bakal (ancestor), Eyang/Romo Dipodrono, look at Figure 5. Eyang Dipodrono's promise to bring Ledek Buntung to perform a tayub dance is commemorating this calendrical event. In almost 24 hours of this main event-despite other additional events that last to 5 days - I find this event so joyful. Late in the evening, when the dancer sang some of the traditional pop songs, I saw some group of young men who were in line waiting for their chance to sing and dance together with the Tayub dancers. Older men who were watching them were laughing and smiling. Everyone is just merely happy and deeply engage with each other, showing the distinct nature of communitas.

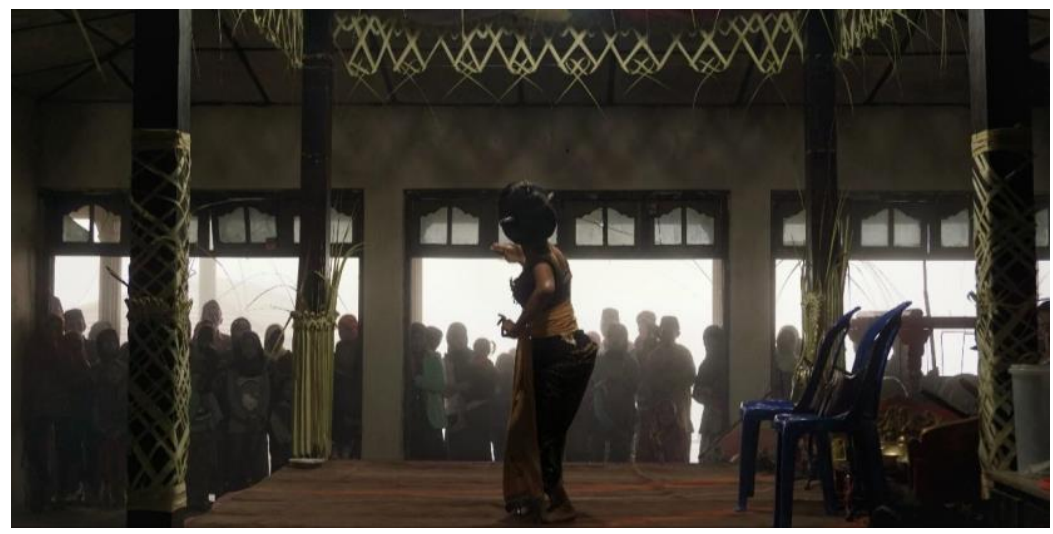

Fig. 5. Twenty-four hours tayub dance performance

A night before rejeban in Gejayan sub-village, mount Merbabu, one large group of the family did mujahadah in the sacred fountain, known as Telompak. That performance, they call as mujahadah, is a series of dzikir (remembering God) reciting tahlil and Yasin, which then followed by a slight moment of silence. This performance, however, is not a required activity in the Rejeban ceremony. This group of families did it as their own. There is no fixed requirement of what kind of rite people must do in Telompak. People who consider themselves Muslim can do a series of dzikir or mujahadah while others can burn incense, place an offering, meditation, or else. Telompak is inherently communitas in itself. It is where people from much background can meet in the same place, accepting the fundamental differences while honoring the same "power" they might differ in interpretation. The same thing is common is nobody dares to come to destruct this place or brave enough to insult whoever "being" believed to live in this very place. People who had ever visit this place would come back to believe that there are other "powerful beings" amid what they can perceive sensually. It is the "liminality," 
the activity mode of Telompak that destruct any structure or status of men to be equal among others bringing them to feel what is called as communitas

Despite cleaned up almost every day by numbers of people who come to visit, this sacred fountain must always be cleaned up on every crucial day commemorated by the community. There are two crucial moments when Telompak is cleaned up; those are in the month Rejeb when Merti Dusun is held and in the month of Ramadhan (according to the Islamic calendar) before the $5^{\text {th }}$ of Syawal when the tradition of Sungkem Telompak is held. As like Ingkung Sewu, the name of Sungkem Telompak also came up quite recently. It is Riyadi, one among many elders from Gejayan, who is also members of KLG, who gave that name. The ritual of Sungkem Telompak, in which people from the Keditan sub-village are coming to the fountain in some particular days after Ied Al-Fitr to pray and perform a dance, was held every year since a long time ago. However, it was never intended to be managed for a public audience. Riyadi is one who has an idea to promote this event to the broader audiences, to arrange this event in quite more professional event-organizer-alike, to give it an exact schedule, and to name it to be Sungkem Telompak. As Supadi, Riyadi shows the creativity that is considered as a significant element of maintaining communitas.

\subsection{The Festival Lima Gunung and The Re-enforcement of Communitas}

FLG, an acronym for Festival Lima Gunung (Five-Mountain Festival), was firstly named as Five Mountain Dance Festival (2002-2005) - these four of the first festivals are also known as FLG I-IV. In 2006, the name was changed to be Festival Seni Lima Gunung and was then renamed to be Festival Lima Gunung in 2010. Five Mountain Dance Festival (the first name) was named by Sutanto and San Flakelar, Amanjiwo Hotel manager [1]. The first four years of this festival seems to be intentionally arranged for commercial purpose since the festival was held as dinner spots for international guests of Amanjiwo hotel. The contract was signed by Eko Sanyoto (the committee leader of the festival) and Hotel Amanjiwo resort, while Sutanto was recognized as the cultural advisor for the festival. The contract explains the role of the committee to hold the festival and Hotel Amanjiwo as its funding resource. However, though a capital funded the first four years of KLG, Sutanto insisted that FLG would be held without denying its very sources, their local knowledge.

FLG was conceptually arranged according to "the ritual processions" such as Merti Dusun in the communities in KLG in which each sub-village is arranging a post-farming ceremony by performing many kinds of traditional performing arts. This concept is proven by the fact that the festival is still held annually in the next 14 years (2006-2020), and may keep in this way, without any commercial resources of funding. If it were not because of the re-enforcement of the local worldview, FLG would have been collapsed - instead of being developed as we can see today-without any sponsorship. Since 2006, Amanjiwo Hotel no longer gave any funding to FLG. To close the gap of the lack of its financial resources, FLG ever opened for donations. Some of their community relations came for help by giving their sum of financial contribution. However, as years passed by, this method was considered as not only inefficient but also "socially" destructive. "Donations would only make us think about money. We were getting more distracted of how to share the donations fairly to the performers than thinking about how to practice optimally," Supadi, the leader of KLG, stated in its interview with media [20].

Moreover, they also got another responsible for how the donations could be shared with the villagers who live in the village in which the FLG was held. That made the problems became even worse. Due to this reason, in 2010, Sutanto Mendut initiated a declaration of Sumpah Tanah to express a strong commitment to deny any outside financial contribution to the Festival and to bring back the concept of the festival to its very source, their own "local knowledge" their elements of communitas. The ritual of Sumpah Tanah (The Vow of Earth) was performed in the opening and the closing of eight day event of FLG IX ( $25^{\text {th }}$ of July to $1^{\text {st }}$ of August 2010) in the peak of Menoreh Mountain, known as the peak of Suroloyo and Studio Mendut. Most performances of FLG IX were held in Studio Mendut, but it was begun with the procession of the Sumpah Tanah ritual, in the early morning of the $25^{\text {th }}$ of July, at the peak of Suroloyo. Wearing Javanese traditional farmer customs-lurik motif as their shirt, black trouser, batik motif as their waist belt, iket as their head cover-those farmersartists of KLG led by Sutanto Mendut climbed the peak of Suroloyo while bringing a 20-meter yellow fabric and some sesaji (offerings) such as nasi tumpeng, ingkung, red and white roses, fruits and vegetables, incenses, and many other else. It is at the peak of Suroloyo that their prayers are said, and their vows are answered. In that place, the "Land Oath" (Sumpah Tanah) is pronounced by farmers- 
artists committed to being responsible for organizing the FLG celebration, and the following is the complete content of the Land Oath (Sumpah Tanah).

- FLG must be held without any sponsorship from the government/company/individual.

- The publication is only allowed through social media to reduce plastic or "visual" waste. Natural resources only make art installation and stage decoration from nearby places.

- The event organizer (local committee from where the event would be held) provides accommodation according to each and its capabilities.

- Anyone is allowed to sell gifts and souvenirs related to Festival Lima Gunung, without any contract with the company, political agencies, or any other organizations.

- The event organizer (Local committee) has the rights to manage culinary and parking sales, without any contract with any outside investor.

- The place where FLG will be held is decided based on "prophecy" and decision from KLG's meeting.

To articulate this vow, each community leader in KLG signed in the piece of land at Studio Mendut as the closing of FLG IX, $1^{\text {st }}$ August 2010. This vow, then, has become the "restored behavior" (Schechner: 1985, 2002, 2013) of FLG that changes the whole performances of FLG as never before. Following Durkheimian's paradigm, Aswoyo (2019, p. 223) sees Sumpah Tanah as "the sacred," which exists to tighten the social rootedness and collectivity. Sumpah Tanah's performance instantly turns FLG to be very similar to saparan, sejeban, Sungkem Telompak, and suran existed in the four communitas in the four mountains. Sumpah Tanah has become "a social ritual" for the whole communitas of KLG. The idea of a community's independence based on all local community events made the performances of FLG, since the FLG IX, to be performed independently; without the need to receive any sponsorship. Though, without funding from outside agencies, instead of collapsing, FLG has made KLG becomes a more intimate community. That is because of the rootedness of FLG as the iconic product of KLG, which has accommodated the existing worldview in each communitas in the four mountains into KLG as the collection of communitas.

Sumpah Tanah is considered a reconstruction event of KLG's local worldview since it is not "an authentic" local worldview, but it is an invention according to them. Though it might be inauthentic, Sumpah Tanah has successfully created "a synchronic bundle," in which as "the reconstruction event," it is recreated not only for a present but for a future to be made graceful through editing, repetition, and invention. Hence, after the performance of Sumpah Tanah, FLG is becoming more similar to the ritual performances of Merti Dusun in Mantran Wetan sub-village (mount Andong) and Krandegan sub-village (mount Sumbing), suran in Tutup Ngisor (mount Merapi), and Sungkem Telompak in Gejayan sub-village (mount Gejayan). This momentum underlines the significance of FLG to be understood as not merely an artistic performance, but also a ritual performance forged by creative endeavor-religious-aesthetic performances which also signifies the interlocked functions of to create beauty and of to deal with the divine or the demonic.

Sumpah Tanah has become "the sacred" as the Ingkung Sewu and Jaran Papat in Mantran Wetan's Merti Dusun, Tayub in Krandegan's Merti Dusun, sacred Wayang Wong in Tutup Ngisor's Suran, and the myth of the sacred fountain in Gejayan's Sungkem Telompak. As a "restored behavior" or a reconstruction event that is gradually becoming an event that is always referred back to and serves as a model and corrective, Sumpah Tanah has mythologized the whole performances of FLG; it brought the sense of rituality into the artistic sphere of FLG. Sumpah Tanah has built a new score to the lives of KLG; this score is a "ritual by contract: fixed behavior that everyone participating agrees to do" [14, p. 37]. The impact of Sumpah Tanah - as a social product - to the lives of KLG also confirms its position as communitas with has liminality, marginality, and structural inferiority as its conditions, which are frequently generated myths, symbols, rituals, philosophical systems, and works of art. These cultural forms are incredibly important, according to Turner, since they "provide men with a set of templates or models with are, at one level, periodical reclassifications of reality and man's relationship to society, nature, and culture" [2]. In other words, communitas is full of creativity. 


\section{Conclusion}

Every performance of communitas works as a vehicle for the construction of multiple meanings and varied religious experiences. In this study, it was found that the idea of community in the case of KLG challenges every structure (culture or religion); they are in the structured/anti-structured. This structured/anti-structured-ness characteristic of communitas is what makes it is vital for the community - that cannot deny the high possibility of contestation of "meaning" within it - to guarantee the balance of social structure and personal status among the people of the community by keep deconstructing-and re-constructing them, so then, they might live peacefully in harmony. That is how the performances of communitas work to be the core of community as social activities that always challenge and shift ongoing relations.

\section{Acknowledgment}

My acknowledgment is given to LPDP (Indonesia Endowment Fund for Education) that has provided me with a scholarship to take this master's program. Financial support from LPDP has helped many Indonesian students to gain higher education in order to develop our nation (Indonesia).

\section{References}

[1] J. Aswoyo and S. Sularso, "The Concept of Panutan in Governance Festival Lima Gunung in Magelang Central Java Indonesia," Harmon. J. Arts Res. Educ., vol. 20, no. 1, pp. 1-9, Jun. 2020, doi: https://doi.org/10.15294/harmonia.v20i1.24818.

[2] V. Turner and R. D. Abrahams, The ritual process: Structure and anti-structure. Routledge, 2017. available at: Google Books.

[3] T. Olaveson, "Collective effervescence and communitas: Processual models of ritual and society in Emile Durkheim and Victor Turner," Dialect. Anthropol., vol. 26, no. 2, pp. 89-124, 2001, doi: https://doi.org/10.1023/A:1020447706406.

[4] F. Bargiela-Chiappini, "Liminal ethnography: understanding segregated organisations," Qual. Res. Organ. Manag. An Int. J., vol. 2, no. 2, pp. 126-143, Aug. 2007, doi: 10.1108/17465640710778520.

[5] A. Guilherme, "Michel Serres' Le Parasite and Martin Buber's I and Thou : Noise in Informal Education Affecting Dialogue Between Communities in Conflict in the Middle East," Educ. Philos. Theory, vol. 47, no. 10, pp. 1052-1068, Aug. 2015, doi: 10.1080/00131857.2015.1031066.

[6] S. Warner and M. A. Dixon, "Understanding Sense of Community From the Athlete's Perspective," $J$. Sport Manag., vol. 25, no. 3, pp. 257-271, May 2011, doi: 10.1123/jsm.25.3.257.

[7] M. Deflem, "Ritual, Anti-Structure, and Religion: A Discussion of Victor Turner's Processual Symbolic Analysis," J. Sci. Study Relig., vol. 30, no. 1, p. 1, Mar. 1991, doi: 10.2307/1387146.

[8] R. Jones, "Inventing rituals; inhabiting places ritual and community in public art," J. Arts Communities, vol. 1, no. 2, pp. 147-167, Dec. 2009, doi: 10.1386/jaac.1.2.147/1.

[9] A. Simpson, "Community. In The Brand Strategist's Guide to Desire," in The Brand Strategist's Guide to Desire, London: Palgrave Macmillan UK, 2014, pp. 19-49. available at: Google Books.

[10] T. C. Davis, Ed., The Cambridge Companion to Performance Studies. Cambridge University Press, 2008. available at: Google Books.

[11] A. Decrop, "Triangulation in qualitative tourism research," Tour. Manag., vol. 20, no. 1, pp. 157-161, Feb. 1999, doi: 10.1016/S0261-5177(98)00102-2.

[12] W. Lu, "Sociology and Art: An Interview with Howard S. Becker," Symb. Interact., vol. 38, no. 1, pp. 127-150, Feb. 2015, doi: 10.1002/symb.139.

[13] D. Harth, "Ritual and Other Forms of Social Action," in Theorizing Rituals, Volume 1: Issues, Topics, Approaches, Concepts, BRILL, 2006, pp. 15-36. available at: Google Books.

[14] R. Schechner, "Between Anthropology and Theatre." Philadelphia: University of Pennsylvania Press, 1985. available at: Google Scholar.

[15] R. Schechner and R. Schechner, Performance studies: An introduction. Routledge, 2017. available at: Google Books. 
[16] C. GODDARD, "Ethnosyntax, Ethnopragmatics, Sign-Functions, and Culture," in Ethnosyntax, Oxford University Press, 2004, pp. 52-73. available at: Google Scholar.

[17] J. Howard-Grenville, K. Golden-Biddle, J. Irwin, and J. Mao, "Liminality as Cultural Process for Cultural Change," Organ. Sci., vol. 22, no. 2, pp. 522-539, Apr. 2011, doi: 10.1287/orsc.1100.0554.

[18] V. Turner and R. D. Abrahams, "Liminality and Communitas," in The Ritual Process, Routledge, 2017, pp. 94-130. available at: Google Books.

[19] A. Van Gennep, “The Rites of Passage, trans. Monika B. Vizedom and Gabrielle L. Coffee.” Chicago: University of Chicago Press, 1909. available at: Google Scholar.

[20] Regina Rukmorini, "Komunitas Lima Gunung dan Seni yang Hidup dari Keringat Petani," Kompas. [Online]. Available: https://interaktif.kompas.id. 